Sulistyo Budiarto', Haniek Farida $^{2}$, Jatu Anggraeni ${ }^{3}$, Fianisa Filmanda ${ }^{4}$

' Fakultas Psikologi, Universitas Sarjanawiyata Tamansiswa Email: st.budiarto@ustjogja.ac.id

\section{Terapi Progressive Muscle Relaxation Mandiri bagi Perempuan dalam Menghadapi Stress Pandemi COVID-19}

\author{
DOI: 10.18196/berdikari.v9i2.11960
}

\section{ABSTRACT}

Women groups are vulnerable to psychological issues during Covid-19. The burden of domestic work and household problems can trigger stress and anxiety for them. The purpose of this community service is to reduce stress levels in women using progressive muscle relaxation techniques. The progressive muscle relaxation technique is the simplest and easiest relaxation method, simply by tensing and relaxing the muscles of the body. This therapy was carried out offline and online in seven sessions. The method for measuring the results of this activity was by a quasi-experimental one-group pretest-posttest design model. The community service was located in Padukuhan Ngelorejo, Gari, Wonosari, Yogyakarta Special Region, involving women PKK cadres. The results showed an effect of manipulation of progressive muscle relaxation therapy on reducing stress levels. Based on these results, there was a decrease in stress levels in participants after a progressive muscle relaxation therapy session. The effect of physical changes felt by participants was in the form of a lighter and relaxed body condition, while the psychological impact was a feeling of calm and comfort. Through the modules and video tutorials, participants were expected to facilitate progressive muscle relaxation therapy techniques to others independently.

Keywords: covid-19, women, progressive muscle relaxation, stress.

\section{ABSTRAK}

Kelompok perempuan rentan mendapatkan problem psikologis di masa pandemi Covid-19. Beban pekerjaan domestik dan problematika rumah tangga, dapat memicu stress dan kecemasan bagi perempuan. Tujuan dari pengabdian masyarakat ini adalah mengurangi tingkat stress perempuan menggunakan tehnik progressive muscle relaxation. Tehnik progressive muscle relaxation adalah metode relaksasi yang paling sederhana dan mudah dipelajari, hanya dengan menegangkan dan merilekskan otot-otot tubuh. Terapi ini dilakukan secara offline dan online dilakukan dalam tujuh sesi terapi. Metode dalam pengukuran hasil kegiatan ini menggunakan rancangan kuasi eksperimen model one group pretest posttest design. Pengabdian masyarakat ini berlokasi di Padukuhan Ngelorejo, Gari, Wonosari, Daerah Istimewa Yogyakarta melibatkan perempuan kader PKK sebagai partisipan. Hasilnya menujukkan ada pengaruh manipulasi terapi progressive muscle relaxation terhadap penurunan tingkat stress. Terdapat penurunan tingkat stress pada partisipan setelah melakukan sesi terapi progressive muscle relaxation. Efek perubahan fisik yang dirasakan oleh partisipan berupa lebih ringan, rileks sedangkan dampak psikologis yang dirasakan berupa perasaan tenang dan nyaman. Modul dan video tutorial yang diberikan kepada partisipan mampu memfasilitasi teknik terapi 
progressive muscle relaxation secara mandiri dan orang lain yang membutuhkan.

Kata kunci: Covid-19, Perempuan, progressive muscle relaxation, Stress.

\section{PENDAHULUAN}

Setahun sudah Indonesia menghadapi situasi pandemi covid-19. Belum ada pihak mana pun yang mampu memprediksi pandemi akan berakhir. Tentu saja, hal ini menjadi kabar buruk bagi masyarakat terdampak. Ancaman penularan covid-19, ketidakstabilan ekonomi, serta pembatasan ruang gerak sosial masih mengintai masyarakat.

Semakin banyak orang yang terpapar covid-19 akan meningkatkan kecemasan. Selain itu, kematian orang terdekat akibat paparan virus berdampak pada kesejahteraan psikologis. Menurut satgas covid-19 per 12 Maret 2021 tercatat 1.410 .130 orang terpapar covid-19, dengan angka kematian mencapai 38.229 orang. Sementara itu, di daerah Istimewa Yogyakarta terdapat 29.636 orang yang telah terpapar covid-19 (Komite Penanganan Covid-19 dan Pemulihan Ekonomi Nasional, 2021).

Ketidakstabilan ekonomi akan memengaruhi tingkat pendapatan masyarakat. Pembatasan sosial akan mempersempit ruang gerak pemenuhan kebutuhan masyarakat. Berdasarkan data Kementerian Ketenagakerjaan (Kemnaker) per 7 April 2020, akibat pandemi covid-19, tercatat 1.010.579 orang pekerja yang terkena dampak ini. Ada 873.090 pekerja dari 17.224 perusahaan dirumahkan serta 137.489 pekerja di-PHK dari 22.753 perusahaan. Di sektor informal sebanyak 34.453 perusahaan dengan 189.452 orang pekerja terdampak. Apabila dicermati, terdapat peningkatan tingkat pengangguran terbuka dari 4,99\% menjadi sekitar 6,17\%-6,65 \% pada Maret 2020. Ini artinya terjadi pengurangan penyerapan tenaga kerja sejumlah 1,6 juta hingga 2,3 juta orang (Rizal, 2020).

Perempuan merupakan individu yang paling rentan mengalami stres saat pandemi covid-19. Di Indonesia, yang masih cenderung patriarkhis, perempuan cenderung memiliki tingkat kerentanan stres yang tinggi. Arivia (2020) menyebutkan bahwa dalam situasi krisis, perempuan selalu berpotensi paling rentang menjadi korban. Hal ini disebabkan dalam keadaan krisis, ketimpangan, kesenjangan, eksploitasi, diskriminasi, dan kekerasan selalu hadir.

Mengacu pada data desa, sebagian besar perempuan di Desa Gari memiliki aktivitas pekerjaan mengurus rumah tangga, seperti terlihat pada Tabel 1. Aktivitas pekerjaan selanjutnya adalah sebagai petani, buruh harian lepas, wiraswasta, karyawan, serta pegawai negeri sipil. Pada saat pandemi covid-19 terjadi perubahan dalam aktivitas pekerjaan. 
Perubahan ini dapat berupa beban yang bisa jadi menjadi pemicu stres bagi perempuan Desa Gari. Salah satunya adalah perubahan peran menjadi pendamping anak belajar.

\begin{tabular}{lcc} 
Tabel 1. Data Pekerjaan Kelompok Perempuan Desa Gari Wonosari Gunung Kidul \\
\hline \multicolumn{1}{c}{ Pekerjaan } & \multicolumn{2}{c}{ Jumlah } \\
\cline { 2 - 3 } & Angka & Persentase \\
\hline Mengurus Rumah Tangga & 1.043 & $15,49 \%$ \\
\hline Petani/Perkebunan & 664 & $9,6 \%$ \\
\hline Pelajar/Mahasiswa & 502 & $7,46 \%$ \\
\hline Buruh Harian Lepas & 132 & $1,96 \%$ \\
\hline Wiraswasta & 220 & $3,27 \%$ \\
\hline Karyawan Swasta \& Honorer & 148 & $2,20 \%$ \\
\hline Pegawai Negeri Sipil (PNS) \& Guru & 55 & $0,91 \%$ \\
\hline
\end{tabular}

Sumber: https://www.gari-wonosari.desa.id/first/statistik/pekerjaan

Problematika yang dihadapi kelompok perempuan di Desa Gari saat mendampingi anak belajar di rumah cukup beragam. Mulai dari kesulitan menggunakan gadget, kesulitan memahami materi belajar sekolah anak, serta kelelahan karena membagi waktu dengan pekerjaan lain. Dampaknya, mereka sering mudah marah, merasa kurang sabar, dan mengalami kelelahan fisik serta psikologis.

Penerapan kebijakan WFH (work from home) dan pembatasan sosial berskala besar yang dicetuskan pemerintah berdampak pada penutupan aktivitas belajar anak di sekolah. Anak-anak diwajibkan belajar di rumah bersama orang tuanya sebagai pengganti guru di sekolah. Tidak bisa dipungkiri, peran guru di rumah dibebankan pada perempuan sebagai ibu. Hal ini tentu saja menambah beban pekerjaan perempuan, selain melakukan aktivitas pekerjaan di luar rumah, rumah tangga, ditambah lagi berperan menjadi guru di rumah saat WFH (Sulaeman \& Salsabila, 2020).

Situasi ini apabila tidak dikelola dengan bijak akan memiliki kecenderungan kuat menjadi pemicu stres pada kelompok perempuan. Berbagai studi menyebut bahwa kondisi pandemi covid-19 menyebabkan masyarakat rentan mengalami stres (Mazza et al., 2020; Odriozola-González et al., 2020; Rehman et al., 2021; Verma \& Mishra, 2020; Zhou et al., 2020). Ditambah lagi, terdapat situasi pemicu khusus dalam kondisi pandemi, yakni kekhawatiran pada pandemi, kehilangan orang terdekat, serta kehilangan pekerjaan.

Sebagai kelompok paling rentan, perempuan membutuhkan bantuan psikologis agar tidak mengalami degradasi kesejahteraan psikologis. Penguatan kesehatan mental dapat berupa intervensi psikologis, fasilitasi ekspresi emosional, strategi mengelola kecemasan, dan lain sebagainya (Ornell et al., 2020). Keterampilan mengelola stres akan menjadi 
kunci bagi kesejahteraan psikologis dan sosial (Muslim, 2020).

Mempertimbangkan dampak stres saat pandemi maka sangat penting bagi perempuan untuk mengembangkan keterampilan mengelola stres. Salah satu metode yang efektif untuk mengelola stres adalah menggunakan relaksasi otot progresif (Ilmi et al., 2017; Sari \& Murtini, 2015; Setyaningrum \& Badi'ah, 2018). Relaksasi otot progresif diinisiasi pertama kali oleh Jacobson untuk merelaksasi 16 kelompok otot (McCallie et al., 2006). Menurut Richmond dalam (Livana et al., 2018) relaksasi otot progresif adalah suatu metode relaksasi yang paling sederhana dan mudah dipelajari dengan menegangkan dan merilekskan otot-otot tubuh.

Oleh karena itu, diperlukan upaya penguatan kapasitas dan keterampilan bagi perempuan di Padukuhan Ngelorejo, Gari, Wonosari untuk mengelola stres yang dialami secara mandiri. Pengabdian masyarakat ini bertujuan untuk membekali perempuan dengan keterampilan mengelola stres saat pandemi covid-19. Melalui terapi otot progresif, diharapkan perempuan sebagai kelompok rentan mampu mengembangkan kemampuan dan ketrampilan mengatasi stres saat pandemi sehingga berdampak positif untuk meningkatkan kesejahteraaan psikologis.

\section{METOdE PELAKSANAAN}

Penelitian dilakukan melalui pendekatan kuantitatif, dengan rancangan kuasi eksperimen dengan desain satu kelompok, model one group pretest posttest design. Pada desain ini dilakukan pengukuran tingkat stres yang telah dimiliki subjek. Setelah diberikan manipulasi berupa terapi otot progresif maka dilakukan pengukuran kembali terhadap tingkat stres subjek dengan alat ukur yang sama. Prosedur relaksasi ini dibagi menjadi tiga tahap seperti terlihat pada Gambar 1.

\section{Pengukuran (O1) $\longrightarrow$ Manipulasi $(\mathrm{X}) \longrightarrow \quad$ Pengukuran (O2)}

Gambar 1. Simbol Desain Tahapan Pengukuran Relaksasi Otot Progresif

Pengumpulan data dilakukan dengan menggunakan skala stres yang diisi oleh peserta sebelum dan sesudah proses terapi. Relaksasi otot progresif disajikan menggunakan modul progressive muscle therapy dibagi menjadi tujuh sesi dengan durasi waktu 7 hari. Proses penyajian dilakukan secara online (daring) dan secara tatap muka. 


\section{A. Persiapan}

\section{Penyusunan modul relaksasi otot progresif}

Penyusunan modul relaksasi otot progresif mengacu pada Jacobson, untuk merelaksasi 16 kelompok otot (McCallie et al., 2006). Modul ini berisi 3 tahap, yakni persiapan yang harus dilakukan partisipan sebelum melakukan relaksasi, tahap pelaksanaan berisi intruksi dan prosedur 11 gerakan merelaksasi 16 otot, terakhir tahap terminasi. Untuk memudahkan partisipan mengikuti prosedur gerakan relaksasi, modul ini divisualkan dalam bentuk video tutorial.

\section{Penyusunan alat ukur stres}

Penyusunan kuesiener skala perilaku stress mengacu pada Helmi dalam Safaria \& Saputra (2009) yang terdiri dari empat aspek yakni reaksi psikologis, reaksi fisiologis, reaksi kognitif, reaksi tingkah laku.

\section{B. Tahap Pelaksanaan}

\section{Sosialisasi}

Pada tahap ini, kegiatan yang dilakukan adalah mengadakan sosialisasi kepada kader PKK Pedukuhan Ngelorejo, Gari, Wonosari dan Gunung Kidul DIY. Sosialisasi bertujuan untuk menekankan pentingnya kemampuan untuk mengelola stres secara mandiri dan mengetahui beban psikologis perempuan pada saat menghadapi pandemi. Situasi saat tersosialisasi dapat dilihat pada Gambar 2.

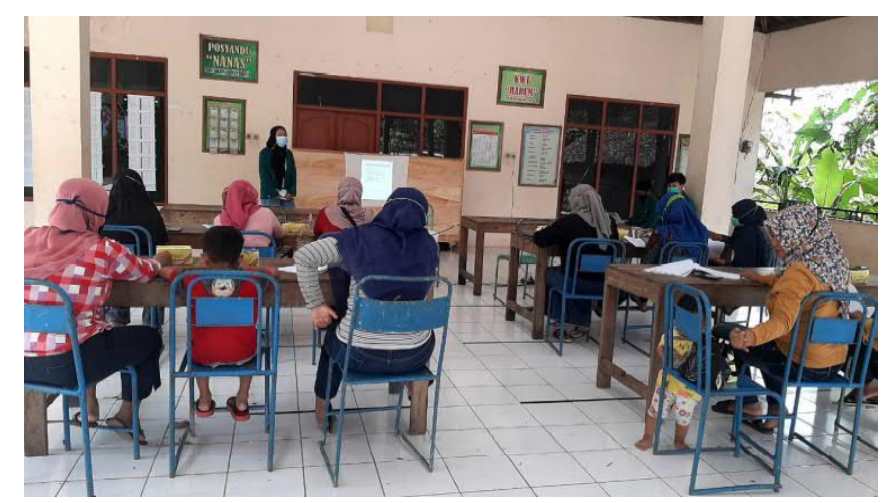

Gambar 2. Kader PKK (Partisipan Kegiatan) Mengikuti Sosialisasi Mengelola Stres di Masa Pandemi dengan Metode Relaksasi

\section{Pelaksanaan Relaksasi}

Mengacu pada penerapan protokol kesehatan, pada tahap pelaksanaan dibagi menjadi dua metode, yakni tatap muka langsung dan daring. Sebelum pelaksanaan relaksasi, partisipan diminta untuk mengisi kuesioner stres pandemi. Prosedur pelaksanaan secara 
daring dicatat dalam catatan harian dan dilakukan di rumah masing-masing partisipan melalui pendampingan seorang fasilitator. Situasi pelaksanaan program terlihat pada Gambar 3.

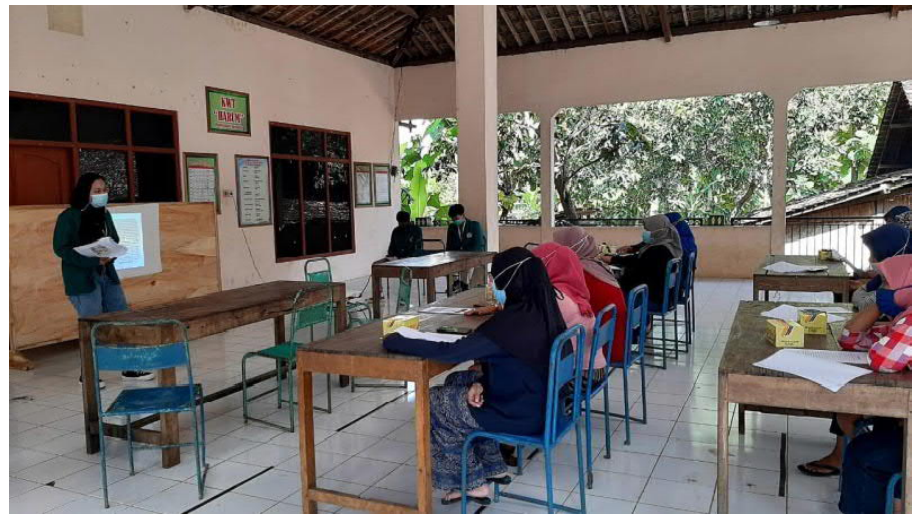

Gambar 3. Partisipan Diperkenalkan dengan Modul Relaksasi Otot Progresif sebagai Awal Kegiatan

\section{Terminasi}

Pada tahap terminasi partisipan diminta untuk mengisi kuesioner skala stres dan diminta untuk menuliskan perubahan, baik secara psikologis ataupun fisik yang dirasakan sebelum dan sesudah pelaksanaan relaksasi.

Partisipan program ini dipilih dengan menggunakan teknik purposive sampling, dengan karakter, yaitu jenis kelamin perempuan, ibu rumah tangga, dan tingggal di Padukuhan Ngelorejo. Partisipan dalam terapi ini berjumlah enam orang, yaitu ibu rumah tangga di Padukuhan Ngelorejo, Gari, Wonosari, Daerah Istimewa Yogyakarta.

\section{HASIL DAN PEMBAHASAN}

Hasil program ini adalah ada pengaruh manipulasi terapi otot progresif terhadap penurunan tingkat stres, dilihat dari perbedaan mean pretest (O1) sebesar 95,33 dengan mean posttest (O2) sebesar 90,50. Hal ini menunjukkan terjadi penurunan tingkat stres pada subjek penelitian. Analisis uji hipotesis pada penelitian ini tersaji dalam Tabel 1 menggunakan paired samples test.

\begin{tabular}{|c|c|c|c|c|c|c|c|}
\hline \multicolumn{5}{|c|}{ Paired Differences } & \multirow{3}{*}{$\mathrm{t}$} & \multirow{3}{*}{ Df } & \multirow{3}{*}{$\begin{array}{l}\text { Sig (2- } \\
\text { tailed) }\end{array}$} \\
\hline & & & \multicolumn{2}{|c|}{$\begin{array}{l}95 \% \text { confidence internal of the } \\
\text { differences }\end{array}$} & & & \\
\hline Mean & Std.dev & $\begin{array}{l}\text { Std.eror } \\
\text { mean }\end{array}$ & lower & upper & & & \\
\hline 4,833 & 2,994 & 1,222 & 1,691 & 7,976 & 3,954 & 5 & ,011 \\
\hline
\end{tabular}


Berdasarkan Tabel 1 nilai signifikansi sebesar 0,01<0,05 maka dapat ditarik kesimpulan bahwa ada perbedaan tingkat stres yang signifikan antara sebelum dilakukannya manipulasi terapi otot progresif dengan sesudah dilakukannya terapi otot progresif. Hal ini menunjukkan bahwa terapi otot progresif mampu menurunkan tingkat stres.

Manfaat terapi relaksasi otot progresif juga didukung dengan data kualitatif berupa catatan harian partisipan seperti terlihat pada Gambar 4. Di dalam catatan harian tersebut, partisipan merasakan mengalami perubahan setelah menjalani terapi relaksasi otot progresif. Perubahan efek relaksasi dirasakan secara bertahap, tidak langsung
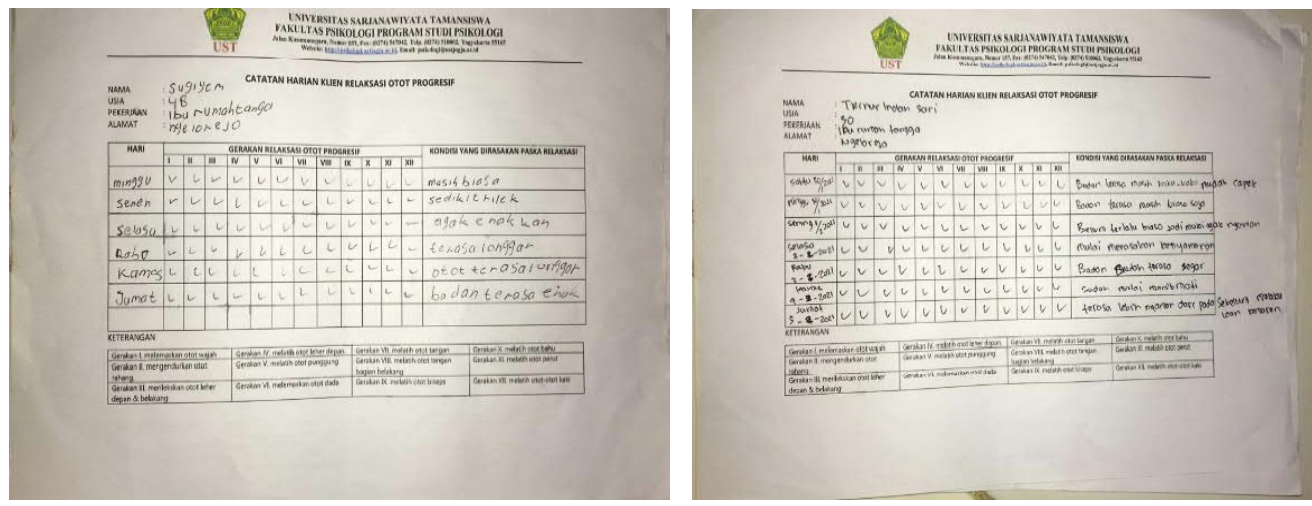

Gambar 4. Catatan Harian Partisipan Program Terapi Otot Progresif

Di awal sesi pertama relaksasi otot progresif, partisipan merasa masih belum terbiasa dan merasakan adanya efek relaksasi. Namun, di sesi ketiga semua partisipan sudah merasakan manfaat relaksasi otot progresif. Efek yang dirasakan partisipan berupa, otot yang rileks, badan ringan, dan menjadi lebih segar. Setelah sesi ketujuh atau terakhir, partisipan merasakan nyaman dan rileks, badan lebih enak dan ringan. Hasil ini sejalan dengan studi dari Xiao, dkk. (2020), yaitu melalui penerapan progressive muscle relaxation pada pasien covid-19 secara signifikan mengurangi stres, kecemasan, dan mood negative. Dampaknya adalah meningkatnya kualitas tidur yang baik pada pasien covid-19 pada saat menjalankan isolasi mandiri.

Dibandingkan dengan jenis terapi yang memiliki tujuan sama, progressive muscle relaxation lebih efektif menurunkan tingkat stres. Studi Azizah, dkk. (2021) menunjukkan bahwa progressive muscle relaxation lebih maksimal menurunkan tingkat stres dibandingkan dengan terapi musik Mozart dan terapi napas. Lebih lanjut, progressive muscle relaxation menstimulasi keluarnya endorfin sehingga dapat menurunkan stres.

Pandemi covid-19 memberikan tekanan stres luar biasa, terutama pada ibu-ibu rumah 
tangga. Peran ganda yang harus dijalani oleh perempuan di masa pandemi merupakan salah satu sumber stres yang mengancam kondisi psikologis (Hapsari, 2020). Partisipan dalam penelitian ini menunjukkan bahwa tekanan stres akibat situasi pandemi dapat dikurangi dengan melakukan progressive muscle relaxation.

Stres adalah suatu kondisi terjadinya tekanan mental pada individu yang sedang menghadapi permasalahan yang berujung pada munculnya berbagai penyakit (Bhargava dan Trivedi 2018). Boals dan Banks (2020), menyebut bahwa stres juga dinilai sebagai situasi yang menyerap energi kognitif yang sangat tinggi. Akibatnya, individu yang mengalami stres menunjukkan penurunan produktivitas kerja. Menurut Navarro-Abal, dkk. (2018), seseorang yang kehilangan pekerjaan akan mengalami kecenderungan depresi dan kecemasan. Dampak stres yang ditimbulkan pun bervariasi pada individu. Orang lebih cenderung takut tertular dan mengalami gejala berat atau sekarat, merasa tidak berdaya, dan menjadi stereotip terhadap orang lain (Kaligis et al., 2020; Xiang et al., 2020), dan gangguan tidur (Huang \& Zhao, 2020).

Dengan beban pekerjaan domestik yang sehari-hari dilakukan, perempuan dinilai memiliki kecenderungan lebih tinggi untuk stres karena harus mendampingi anak belajar di rumah. Kondisi ini bertambah berat apabila suami mengalami stres kerja. Suami yang harus bekerja dari rumah atau bahkan tidak bekerja, menganggur di rumah, akan mengakibatkan terjadinya penurunan produktivitas dan pemasukan. Hal inilah yang menjadikan perempuan memiliki kerentanan mengalami stres lebih tinggi. Hal tersebut sejalan dengan Lin, dkk. (2019) mengenai konflik peran ganda yang memiliki pengaruh negatif bagi kesejahteraan psikologis.
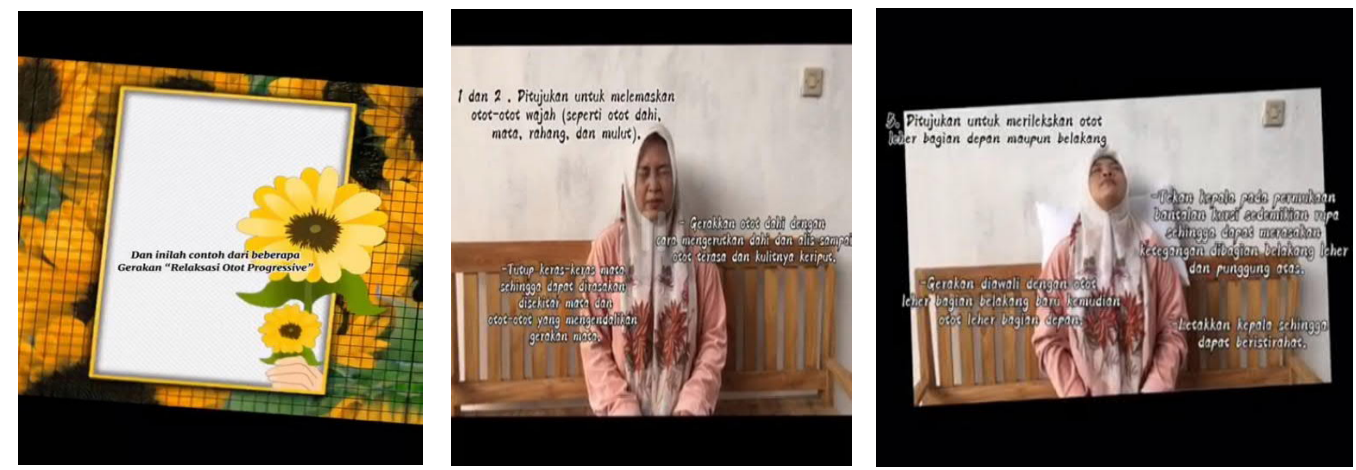

Gambar 5. Bagian Video Tutoria/ Progressive Muscle Relaxation

Keberhasilan terapi otot progresif pada partisipan ibu rumah tangga di Ngelorejo, mengonfirmasi hasil lain tentang efektivitas progressive muscle relaxation menurunkan tingkat stres (Ilmi et al., 2017; Kusnanto et al., 2019; Sari \& Murtini, 2015; Setyaningrum 
\& Badi'ah, 2018). Manfaat yang dirasakan, baik secara fisik maupun psikologis juga sama, yakni secara fisik badan menjadi ringan, rileks, dan segar, sedangkan secara psikologis, perasaan nyaman dirasakan oleh partisipan.

Peran modul relaksasi otot progresif dan pendampingan yang disertai video tutorial (seperti terlihat pada Gambar 5) yang diberikan merupakan bagian penting yang mendukung kegiatan relaksasi ini. Meskipun begitu, di dalam prosesnya terdapat partisipan yang tidak rutin melakukan sesi. Namun demikian, kelemahan ini tidak mempengaruhi hasil yang diperoleh dalam program ini.

\section{SIMPULAN}

Ada perbedaan tingkat stres yang signifikan antara sebelum dilakukannya manipulasi terapi otot progresif dengan sesudah dilakukannya terapi otot progresif. Hal ini menunjukkan bahwa terapi otot progresif mampu menurunkan tingkat stres perempuan menghadapi pandemi. Dengan demikian, partisipan diharapkan dapat melakukan relaksasi otot progresif secara mandiri dan mampu menjadi peer educater di komunitasnya untuk mengelola stres saat menghadapi pandemi covid-19.

\section{UCAPAN TERIMA KASIH}

Ucapan terima kasih disampaikan kepada pemerintah Padukuhan Ngelorejo, Gari, Wonosari, Gunung Kidul, Daerah Istimewa Yogyakarta yang telah mendukung dan memfasilitasi kegiatan terapi mandiri relaksasi otot progresif. Terima kasih juga disampaikan kepada Universitas Sarjanawiyata Tamansiswa atas dukunganya hingga kegiatan ini dapat berjalan dengan lancar.

\section{DAFTAR PUSTAKA}

Arivia, G. (2020, May 11). Feminisme dan Covid-19. http://www.jurnalperempuan.org/wacanafeminis/feminisme-dan-covid-19

Azizah, F. N., Sumarni, S., Sukowati, F., \& Kumorowulan, S. (2021). The Effectiveness of Progressive Muscle Relaxation and Mozart Music Therapy on Premenstrual Syndrome Stress Scores. JURNAL KEBIDANAN, 111), 10-14. http://ejournal.poltekkes-smg.ac.id/ojs/ index.php/jurkeb/article/view/6278

Bhargava, D., \& Trivedi, H. (2018). A Study of Causes of Stress and Stress Management among Youth. IRA-International Journal of Management \&
Social Sciences (ISSN 2455-2267), 113), 108 https://doi.org/10.21013/jmss.v11.n3.p1

Boals, A., \& Banks, J. B. (2020). Stress and cognitive functioning during a pandemic: Thoughts from stress researchers. Psychological Trauma: Theory, Research, Practice, and Policy, 12(S1), S255-S257. https://doi.org/10.1037/tra0000716 Hapsari, I. (2020). Konflik peran ganda dan kesejahteraan psikologis pekerja yang menjalani Work From Home pasca Pandemi COVID-19. Jurnal Psikologi, 13(1), 37-45. https:// doi.org/10.35760/psi.2020.v13i1.2623 Huang, Y., \& Zhao, N. (2020). Generalized anxiety 
disorder, depressive symptoms and sleep quality during COVID-19 outbreak in China: a web-based cross-sectional survey. Psychiatry Research, 288, 112954. https://doi.org/10.1016/ j.psychres.2020.112954

Ilmi, Z., Dewi, E., \& Rasni, H. (2017). Pengaruh relaksasi otot progresif terhadap tingkat stres narapidana wanita di lapas kelas IIA Jember. Pustaka Kesehatan.

Kaligis, F., Indraswari, M. T., \& Ismail, R. I. (2020). Stress during COVID-19 pandemic: Mental health condition in Indonesia. Medical Journal of Indonesia, 29(4), 436-441. https://doi.org/ 10.13181/mji.bc. 204640

Kusnanto, K., Murtadho, M. A., Herawati, L., \& Arifin, $H$. (2019). The comparison of progressive muscle relaxation frequency on anxiety, blood pressure, and pulse of haemodialysis patients. Jurnal Ners, 14(1), 69-74. https://ejournal.unair.ac.id/JNERS/article/view/15700

Lin, W. R., Chen, H. M., \& Wang, Y. C. (2019). Workfamily conflict and psychological well-being of tour leaders: The moderating effect of leisure coping styles. Leisure Sciences, 1-22. https:// doi.org/10.1080/01490400.2019.1671253

Livana, P., Daulima, N. H. C., \& Mustikasari. (2018). Relaksasi otot progresif menurunkan stress kelurga yang merawat pasien gangguan jiwa. Jurnal Keperawatan Indonesia, 211), 51-59. https://doi.org/10.7454/jki.v21i1.362

Mazza, C., Ricci, E., Biondi, S., Colasanti, M., Ferracuti, S., Napoli, C., \& Roma, P. (2020). A nationwide survey of psychological distress among italian people during the covid-19 pandemic: Immediate psychological responses and associated factors. International Journal of Environmental Research and Public Health, 179). https://doi.org/10.3390/ijerph17093165

McCallie, M. S., Blum, C. M., \& Hood, C. J. (2006). Progressive muscle relaxation. In Journal of Human Behavior in the Social Environment (Vol. 13, Issue 3, pp. 51-66). https://doi.org/10.1300/ J137v13n03_04

Muslim, M. (2020). Manajemen stress pada masa pandemi COVID-19. ESENS/: Jurnal Manajemen Dan Bisnis, 23(2), 192-201.

Navarro-Abal, Y., Antonio Climent-Rodríguez, J., José López-López, M., \& Gómez-Salgado, J. (2018). Psychological coping with Job Loss. Empirical study to contribute to the develop- ment of unemployed people. https://doi.org/ 10.3390/ijerph15081787

Odriozola-González, P., Planchuelo-Gómez, Á., Irurtia, M. J., \& de Luis-García, R. (2020). Psychological symptoms of the outbreak of the COVID19 confinement in Spain. Journal of Health Psychology, 135910532096708. https://doi.org/ 10.1177/1359105320967086

Ornell, F., Halpern, S. C., Paim Kessler, F. H., \& de Magalhães Narvaez, J. C. (2020). The impact of the COVID-19 pandemic on the mental health of healthcare professionals. Cadernos de Saude Publica, 36(4), 1-6. https://doi.org/10.1590/0102$311 \times 00063520$

Peta Sebaran COVID-19. (2021, March 11). Komite Penanganan Covid 19 Dan Pemulihan Ekonomi Nasional. https://covid19.go.id/peta-sebarancovid19

Rehman, U., Shahnawaz, M. G., Khan, N. H., Kharshiing, K. D., Khursheed, M., Gupta, K., Kashyap, D., \& Uniyal, R. (2021). Depression, Anxiety and Stress Among Indians in Times of Covid-19 Lockdown. Community Mental Health Journal, 57(1), 42-48. https://doi.org/10.1007/ s10597-020-00664-x

Rizal, J. (2020, November 8). Pandemi Covid-19, Apa Saja Dampak pada Sektor Ketenagakerjaan Indonesia? Kompas.Com, 1. Pandemi Covid-19, Apa Saja Dampak pada Sektor Ketenagakerjaan Indonesia?\%0A\%OAArtikel ini telah tayang di Kompas.com dengan judul \%22Pandemi Covid19. Apa Saja Dampak pada Sektor Ketenagakerjaan Indonesia?\%22, Klik untuk baca: https://www.kompas.com/tren/

Safaria, T. dan Saputra, N. E. (2009). Manajemen emosi: Sebuah panduan cerdas bagaimana mengelola emosi positif dalam hidup anda. Jakarta: Bumi Aksara

Sari, H. F., \& Murtini, M. (2015). Relaksasi untuk mengurangi stress pada penderita hipertensi esensial. HUMANITAS, 12(1), 12. https://doi.org/ 10.26555/humanitas.v12i1.3823

Setyaningrum, N., \& Badi'ah, A. (2018). Efektivitas progressive muscle relaxation dengan zikir terhadap penurunan tekanan darah dan penurunan tingkat stres pada penderita hipertensi. MEDISAINS, 16(1), 8. https://doi.org/ 10.30595/medisains.v16i1.1400

Sulaeman, K. M., \& Salsabila, F. R. (2020). Dampak 
COVID-19 terhadap kaum perempuan:

Perspektif feminisme. Jurnal Sentris, 12), 159-

172. https://doi.org/10.26593/

SENTRIS.V112.4283.159-172

Verma, S., \& Mishra, A. (2020). Depression, anxiety, and stress and socio-demographic correlates among general Indian public during COVID-19. International Journal of Social Psychiatry, 66(8), 756-762. https://doi.org/10.1177/ 0020764020934508

Xiang, Y. T., Yang, Y., Li, W., Zhang, L., Zhang, Q., Cheung, T., \& Ng, C. H. (2020). Timely mental health care for the 2019 novel coronavirus outbreak is urgently needed. In The Lancet Psychiatry (Vol. 7, Issue 3, pp. 228-229). Elsevier Ltd. https://doi.org/10.1016/S22150366(20)30046-8

Xiao, C.-X., Lin, Y.-J., Lin, R.-Q., Liu, A.-N., Zhong, G.Q., \& Lan, C.-F. (2020). Effects of progressive muscle relaxation training on negative emotions and sleep quality in COVID-19 patients A clinical observational study. https://doi.org/10.1097/ MD.0000000000023185

Zhou, S. J., Zhang, L. G., Wang, L. L., Guo, Z. C., Wang, J. Q., Chen, J. C., Liu, M., Chen, X., \& Chen, J. X. (2020). Prevalence and sociodemographic correlates of psychological health problems in Chinese adolescents during the outbreak of COVID-19. European Child and Adolescent Psychiatry, 29(6), 749-758. https:// doi.org/10.1007/s00787-020-01541-4 